\title{
Study on the Strategies of Service-Based Education in University Library
}

\author{
Jing Xiong \\ College of Engineering Technology, Yangtze University \\ Jingzhou of China
}

\begin{abstract}
Comprehensive research method has been applied in this study to discuss the divine purpose of service-based education in university library and analyze the characteristics of service-based education. Compared with teaching education and management education, service-based education has been with the characteristics of intuition, demonstration, flexibility, penetrability and appealingness. The basic strategies for librarian to improve the quality of service-based education have been proposed as follows: enhancing self-quality, strengthening demonstration effect of librarians, mastering reading regularity of readers, improving service quality and efficiency, enriching collection, ameliorating conditions of library, optimizing reading situation, building a sound system of management and regulating the behaviors of the librarian.
\end{abstract}

Keywords- library; service-based education; subject librarian; behavior criterion

\section{INTRODUCTION}

University library has a natural condition for the service-based education. A large number of books, magazines, newspapers and various kinds of audio-visual resources purchased by school are collected in library. Library, as an artificial thesaurus, provides a specific place with self-study materials for teachers and students. Therefore, library is with naturally educational function. Librarians work as demonstrators for students from multi-aspects to play roles of exerting subtle influences on education, with their enthusiasm, normative behaviors, expert skills, high efficiency and affluent materials. This education, providing a favorable environment for students to cultivate their ideological morality, personality, intelligence and ability, has irreplaceable function for undergraduates to be talent(1). Thus, the position and function of university library should be paid high attention to instead of being underestimated. Then, how does university library accomplish the service-based education?

\section{ENHANCE SELF-QUALITY AND STRENGTHEN DEMONSTRATION EFFECT OF LIBRARIANS}

Librarians, as educators of college without giving lessons, will influence students by their service and demonstration effects. Besides, librarians set exemplary roles for students by their own statement and actions. Therefore, librarians in university should establish three types of ideas(2). First, it is the idea of being exemplary roles. In order to meet this requirement, librarians have to reinforce their attitude towards being good examples and know well about the principle of "details determine success or failure, and words and needs decide fascination". Librarians educate students by their attitude, efficiency and quality of service performed in work. Strengthening personal moral character and accomplishment of words and deeds as well as improving the personality charm with self-awareness are needed in their daily work. Second, it is to establish the idea of service paramount. Librarians have to influence students by taking practical actions gradually, such as respecting and cherishing their own post, giving part of themselves away as assistants with patience and circumspection, while greeting students with a broad smile positively. Third, it is the idea of being considerate. As a librarian of university, he not only needs to have deep love for his job with hospitable service, but also comprehend the needs of students by considering problems from the perspective of readers. Being considerate, librarians are able to satisfy students' needs with passionate and honest attitude, gentle and polite language, and spontaneous and voluntary actions. Their decent behaviors have shortened their distance with readers, creating a harmonious relationship with readers to found a favorable environment and atmosphere for them. On the basic of mutual trust and mutual comprehension, librarians and readers will keep a harmonious relationship, during which readers may be considerate when their demands can not be satisfied as soon as possible. As we all know that, the mutual understanding is the precondition of first-rate service. If a librarian can not cope with the requirement of readers, the readers might feel regretful no matter how good attitude he has kept. Such an experience will drive librarians' service to a passive and embarrassing situation. A bad impression will be left, when librarians are not familiar with business or they can not process business as soon as possible. Therefore, as a librarian in university, being enthusiastic when providing service is not enough, and higher professional proficiency and work level are needed as well. A good professional quality, as the important guarantee of improving service quality and level, is also the precondition for better education. From this perspective, librarians should be required to acknowledge professional knowledge in a planed way to enrich and improve their service skills. At the same time, the school authorities should attach great importance to the structural improvement of librarians and the problems about improving quality of librarians. Hence, the school authorities should provide the conditions for training the staff from different perspectives to enhance their professional quality and productive capacity. The ideal situation is that through learning and practicing, each librarian can be trained as a master or "expert" in the field of library science gradually, and also as an "Eclectics", who is armed with broad scope of knowledge, dabbling at multiple disciplines (3). 


\section{MASTER READING REGULARITY OF READERS, AND IMPROVE SERVICE QUALITY AND EFFICIENCY}

The librarian, the deliver and developer of knowledge, has worked as the guide for readers to appreciate the fascination of books. The level of librarian's professional quality will influence that of service quality and level directly so as to influence the realization about purpose of library service-based education. First, it is to understand the reading demands of different readers. Reading demands vary form reader to reader. For example, when a freshman readd, he prefers to give priority to killing time without specific direction. At the beginning of university life, undergraduates are curious about the new life, but they have made no sense of any professional fields. Therefore, when the reading targets are ambiguous, their reading will be confined to blindness and randomness. For freshmen, hierarchy of needs towards to reading materials is lower, because they read only for their homework or out of extracurricular activities. For students in this hierarchy, on one hand, tutoring about how to use of library should be conducted to help them to acknowledge library resources and guide them to make the most of library; on the other hand, bibliographies could be introduced to them to lead them to read excellent books and periodicals as well as to establish the correct outlook on life and word. Reading purposes of sophomores and juniors are clearer than those of freshmen. They are getting familiar with and becoming accustomed to life of university gradually. And they, who have entered the stage of professional learning, desire to gain more knowledge to enrich and equip themselves with library resources. They have made clear reading purpose, and the reading contents they prefer are filled with obvious specialization and universality; the level of reading needs also has transformed from lower to higher point, in which they are not confined to the ready-made conclusions and begin to reference a lot of books with various opinions and those of different genres. They could make comparison and analysis about these materials by reading, and then get their own opinions and conclusions. For students in this hierarchy, on one hand, tutoring about literature retrieval and utilization should be conducted to help them to increase information consciousness as well as to train them to acquire, accumulate and take advantage of knowledge; on the other hand, they should meet students' strong demand of knowledge by implement the works as follows: cooperating closely with professional teaching, compiling various specific bibliographies and indexes, propagandizing and reporting new books and periodicals, developing comments on books and periodicals, and instructing students to read. Reading of college students in graduate stage is systematic. The seniors have tended to be mature in all aspects in this period. On one hand, the students have to collect abundant information in specific aspect to make preparation for the graduation project (thesis), so that reading is with obvious professional and systematic characteristics; on the other hand, they will broadly read the document literature related to employment, philosophy of life, etiquette for public relations, strategy of competition and management science and so on, because they want to get the information about how to seek a job, how to participate in social competition and how to realize their own value after being graduated. In order to meet the needs of the seniors, many actions can be taken in library: the library can expand the scope and the number of books, which could be borrowed; the lending methods as well as opening hours can also be changed to satisfy the needs of graduates; consulting service window can be especially set for graduates to help them to answer their questions in time. All of these actions could be taken to help them graduate successfully and make them become great assets to socialist modernization. Meanwhile, in order to cultivate innovative talents, reference materials could be provided for students to carry out scientific researches(4).

In a word, when providing service to different groups of readers, it's necessary for librarians to master reading regularity of readers to help them find their desired reading materials as soon as possible, or to put forward reference comments for them. Therefore, the degreed of familiarity about the library resource will affect librarians' work efficiency, such as being able to provide the book information. Librarians could even make an appointment with the readers about the lending time. By these means, the quality of service-based education as well as service quality and efficiency of library can be improved.

\section{ENRICHING COLLECTION, AMELIORATING CONDITIONS OF LIBRARY AND OPTIMIZING READING SITUATION}

Collection of library is the material basis for the library service. Library can provide service for teachers and students by its abundant and fine literature materials to realize the objective of service-based education. It edifies the students' development of ideology and morality. Professional knowledge education, intelligence development and ability training are conducted with the assistant of library. Without the collection of library, the service and education are as making bricks without straw, or water without a source. Therefore, the university library should be for the purpose of educating people. On the basis of demands for school ideological education, professional teaching and scientific research, construction principles and planning of collection development should be made to increase the number of collection and improve the quality of collection. Furthermore, raising funds for purchasing literatures actively and timely procurement of document literatures with high ideological level, academic value and high-usage are also essential to meet the demands of readers on document literatures to the hilt.

\section{BuILDING A SOUND SySTEM OF MANAGEMENT, AND REGULATING THE BEHAVIORS OF THE LIBRARIAN.}

It is necessary to build a normative management system to improve the management efficiency. System construction of university library has been more mature than before. Even if a new library is built, the experience and institutions of other libraries can be regarded as references. But, from the perspective of routine management, little possibility of deeper development exists. The institutional improvement described in this study was a new regulatory framework adapting the development requires under new circumstances. For example, "Personalized Service System" is a system adapting to the needs of personalized development; "Subject Librarian System" is one adapting to the needs of discipline construction; "Directional Service System", "Sharing of Information 
Resources Development and Cooperation System", and "Continuing Education and Training System for Librarians" are all systems adapting to the needs of research development. To establish and promote the system gradually is benefit for the improvement and development of the library with the enforcement of service ability and standards, and benefit for the enlargement of the service function of library.

It is necessary to build a system of subject librarian to strengthen the function of discipline service. The system of subject librarian is a new system for the library to select some librarians, with strong ability of information consultation and retrieval, are familiar with literature information resources in library and with professional knowledge of specific subject. And these librarians have good communication ability with some teachers of relevant professions to provide information service for readers in specific discipline, building follow-up and counterpart service(5). The system of subject librarian is the creation of university library management mechanism under the networks environment. This kind of system has many advantages as follows: meeting the demands of readers from various disciplines for their obtaining professional information resources; being beneficial for the deep development and utilization of information resources in different disciplines; being beneficial for training excellent talents for library; being beneficial for the enhancement to adapt to the disciplinary development needs in the era of knowledge-driven economy; improving the service quality and level of library. In this system, the work of the information service and that of scientific research are combined. On one hand, it will improve the service quality of the library; on the other hand, it will improve the capability and level of librarians gradually by guiding them to combine their work with disciplines or professional teachers' scientific researches.

\section{REFERENCES}

[1] Zhong Yang, etc., The University Library and Quality Education for Undergraduates, Journal of Chongqing University (Social Science Edition), $2001,7(1)$.

[2] Chunju Lei, Cultivating the Students' Comprehensive Ability to Strengthen the Role of University Library in the Cultivation of Talents, Journal of Hubei Automotive Industries Institute, 2004, (3).

[3] Deliang Zeng,Yunsheng Fu, A Brief View of Service-based Education in University Library, Work of University Library, 1998, (1).

[4] Hui Cheng, On the Role of the University Library in Cultivating the Innovative Talents, Journal of Zhuzhou Institute of Technology, 2005, (2).

[5] Huizhu Luo, Haiying Wang, Trial Implementation about the System of Subject Librarian to Deepen the Innovation of Management and Service in University Library, Journal of Precious Library, 2004, (3). 